\author{
Anna Tarwacka \\ Cardinal Stefan Wyszyński University in Warsaw \\ a.tarwacka@uksw.edu.pl \\ ORCID 0000-0002-6171-4117 \\ https://doi.org/10.26881/gsp.2019.3.06
}

\title{
USING LEX RHODIA IN THE CASE OF A PIRATE ATTACK
}

The poet Nikarchos wrote about someone who went to the prophet and asked him how to sail safely to Rhodes. The fortune teller was to answer: 'First of all, take a new ship and do not set out in the winter, only in the summer. ${ }^{1}$ If you do, you'll get there and back, unless a pirate catches you at sea. ${ }^{2}$ This amusing story is the quintessence of what Antiquity thought about maritime transport. It was necessary to sail on a decent ship during the sailing season but even that did not constitute a guarantee of safety.

The sea has always been an unbridled force. It was dangerous but at the same time it allowed quick movement and facilitated trade. Therefore, the ancients, with greater or lesser enthusiasm, benefited from its merits, though often at the expense of a major risk of losing property and above all life.

The threat at sea was caused by treacherous rocks and shallows, violent gales and storms, but also by pirates. ${ }^{3}$ We do not have a legal definition of maritime armed robbery, however, some conclusions can be drawn after analyzing non-legal texts (cf. Tarwacka, 2009, 22 ff.; Tarwacka, 2018b, 53 ff.). Above all, pirates were considered ruthless people who would not spare anyone. ${ }^{4}$ It was believed that they did not respect human or divine laws, and would stop at no lawlessness. Their actions were generally carried out with the use of ships, yet they attacked not only at sea but also on land, ${ }^{5}$ in coastal villages, cities and along routes. They

1 On the sailing season see: Ducin (1997), 59-92; Beresford (2013), passim, in the context of piracy $237 \mathrm{ff}$.

2 Nikarch. Ep. 11,162.

3 On piracy see first and foremost Ziegler (1980); Pohl (1993); Ormerod (1997); Souza (1999); Rauh (2003), 169 ff.; Tarwacka (2009).

4 Plaut. apud Charis. 211: Ita sunt praedones: prorsum parcunt nemini.

5 Flor. Epit. 1.41: sed ut quaedam animalia, quibus aquam terramque incolendi gemina natura est, sub ipso hostis recessu inpatientes soli in aquas suas resiluerunt, et aliquando latius quam prius Siciliae quoque litora et Campaniam nostram subito adventu terrere voluerunt. 
were also armed. ${ }^{6}$ Importantly, not only active complicity in the robbery but the membership in the gang itself constituted a felony. ${ }^{7}$ Piracy was thus a branch of organized crime.

Pirate attacks can be considered as a very important factor affecting the quality and safety of maritime transport. The risk associated with them was perceived as very high. Therefore, such a robbery was subject to legal qualifications on several levels.

D. 39.6.3. Paulus libro septimo ad Sabinum: Mortis causa donare licet non tantum infirmae valetudinis causa, sed periculi etiam propinquae mortis vel ab hoste vel a praedonibus vel ab hominis potentis crudelitate aut odio aut navigationis ineundae.

Paulus recognized that the possibility of making a donation in the event of death existed not only in the case of health problems but also when in danger of imminent death at the hands of enemies, pirates, as a result of cruelty or hatred of an influential man, or an upcoming sea journey. He explained that all these situations are examples of near and violent threats: haec enim omnia instans periculum demonstrant. ${ }^{8}$ Hence a pirate attack was a real danger.

What is more, the attack of sea robbers, as well as an attack of an enemy army, was classified as a force majeure event (cf. Gerkens, 2005, 109 ff.; Sobczyk, 2005, 75 ff.; Tarwacka, 2009, 139 ff.). It was most often described in source texts as vis piratarum, ${ }^{9}$ vis praedonum, ${ }^{10}$ impetus praedonum, ${ }^{11}$ insidiae piratarum, ${ }^{12}$ casus piratarum..$^{13}$ Other sources also point to the fact that the parties anticipated the possibility of a pirate attack. ${ }^{14}$

D. 50.17.23. Ulpianus libro vicesimo nono ad Sabinum: (...) animalium vero casus mortesque, quae sine culpa accidunt, fugae servorum qui custodiri non solent, rapinae, tumultus, incendia, aquarum magnitudines, impetus praedonum a nullo praestantur.

According to Ulpianus, no contract provided for liability for the occurrence of vis maior, including a pirate attack. The phrase a nullo praestantur warrants the presumption that the parties could not extend the scope of responsibility ad in-

\footnotetext{
6 Sen. Contr. 1.2.8: Non est credibile temperasse a libidine piratas omni crudelitate efferatos, quibus omne fas nefasque lusus est, simul terras et maria latrocinantes, quibus in aliena impetus per arma est; iam ipsa fronte crudeles et humano sanguine adsuetos, praeferentes ante se vincula et catenas, gravia captis onera, a stupris removere potuisti, quibus inter tot tanto maiora scelera virginem stuprare innocentia est? Cf. Lentano (2010), $92 \mathrm{ff}$.

7 Sen. De benef. 5.14: Sic latro est etiam antequam manus inquinet, quia ad occidendum iam armatus est et habet spoliandi atque interficiendi voluntatem. Exercetur et aperitur opere nequitia, non incipit.

8 D. 39.6.6 (Paulus libro septimo ad Sabinum).

9 D. 4.9.3.1 (Ulpianus libro quarto decimo ad edictum).

10 D. 35.2 .30 pr. (Maecianus libro octavo fideicommissorum).

11 D. 50.17 .23 (Ulpianus libro vicesimo nono ad Sabinum). Cf. Cic. Ad fam. 4,7.

12 D. 13.6 .18 pr. (Gaius libro nono ad edictum provinciale).

13 D. 13.6 .18 pr. (Gaius libro nono ad edictum provinciale).

14 P. Laur. I 6; P. Köln. III 147. Cf. Jakab (2008), 73 ff.; Alonso (2012), 47 ff.
} 
finitum, and therefore this type of pactum would have been considered invalid. It seems that it would have been contrary to the principles of equity.

It is worth noting that both fragments cited above come from the commentaries to Sabinus written respectively by Paulus and Ulpianus. Therefore it may be assumed that Sabinus was interested in various cases of vis maior and their impact on various contractual relations.

Lack of liability was not the only issue to be resolved. One also needed to decide which party assumed the risk (periculum) of a force majeure event. As a rule, it was the owner of the item to which the contract pertained, but in some cases that rule could be altered. The contractual clause of mеo periculo was used for this puspose, as attested both in legal texts and practice documents (more on this Tarwacka, 2016a, 147 ff.; Tarwacka, 2018a, 130 ff.).

Occurrences at sea compelled crews and passengers of ships to take remedial actions. One of the options was jettison. This very institution will be the subject of further considerations.

Jettison at sea (i.e. iactus, or iactura) is a situation in which goods transported on a ship are thrown overboard in order to relieve it in a situation of the so-called average, or danger. This question was regulated by the lex Rhodia de iactu, which raises many doubts among researchers ${ }^{15}$ who dispute the provenance of norms regulating jettison. The crux of the problem lies in whether they had been copied from the law of the island of Rhodes, or whether they are an independent creation of Roman jurisprudence (cf. Atkinson, 1974; De Martino, 1995, 285 ff.).

The title De lege Rhodia de iactu in Justinian's Digest (D. 14.2) raises many reservations in the doctrine, mainly due to the fact that not all fragments contained there are related to the law of jettison. The fragments of the Basilica (called the pseudo-Rhodian law) that refer to the lex Rhodia do not dispel these doubts ( $c f$. Osuchowski, 1950; Płodzień, 1961, 39-40).

A legal definition of jettison was formulated by Paulus ${ }^{16}$.

D. 14.2.1. Paulus libro secundo sententiarum: Lege Rhodia cavetur, ut, si levandae navis gratia iactus mercium factus est, omnium contributione sarciatur quod pro omnibus datum est.

The law allowed a merchant who had lost his goods as a result of throwing them overboard to relieve the ship to demand the return of some of the value of such goods from other people whose property was carried on that vessel. The actio locati served this purpose and it was brought against the master of the ship (magister navis), who was in turn entitled to recourse claims (in the form of actio conducti) towards other locatores, ${ }^{17}$ and also could retain their goods until the settlement (retentio).

15 On the lex Rhodia see e.g.: Osuchowski (1950); Płodzień (1961); De Martino (1995); Kofanov (2017), 309 ff.

16 Cf. Paulus, Sent. 2.7.1: Levandae navis gratia iactus cum mercium factus est, omnium intributione sarciatur, quod pro omnibus iactum est.

17 D. 14.2.2 pr. (Paulus libro trigensimo quarto ad edictum). Cf. Aubert (2007), 161-163. 
According to Paulus, the reason for jettison was the need to relieve the ship (levandae navis gratia). Situations necessitating such an action undoubtedly included a sea storm, which was mentioned by the jurists commenting on the lex Rhodia: Paulus ${ }^{18}$, Callistratus ${ }^{19}$ and Iulianus ${ }^{20}$.

Curt. Ruf. Hist. Alex. 5.9.4: gubernator, ubi naufragium timet, iactura, quidquid servari potest, redimit.

Having stated that sometimes one needed to make a difficult decision, Curtius Rufus gave an example of a captain who undertook a jettison for fear of wrecking the ship. It was the captain who was responsible for the ship, the crew and the passengers, and it was him who ordered the jettison to happen. ${ }^{21}$

Iuv. Sat. 12,33: cum plenus fluctu medius foret alveus et iam

alternum puppis latus evertentibus undis

arboris incertae, nullam prudentia cani

rectoris cum ferret opem, decidere iactu

coepit cum ventis...

In one of his satires, Juvenal described a sea storm during which the helmsman was no longer able to control the ship. The captain decided to end the futile struggle by carrying out a jettison. The subsequent part of the text shows that this was not a sufficient remedy: it was also necessary to cut the mast down, ${ }^{22}$ but eventually the ship survived and the catastrophe was avoided.

It seems, however, that the crew could have been forced to get rid of unnecessary burden by other circumstances, such as the need to escape the pursuit of a pirate ship. In that case, the decisive role was played by the speed the individual vessel was able to develop, so it can be assumed that the iactus was often a key measure. Pirate ships were usually small and swift, unlike merchant boats; therefore, during the chase, it was necessary to accelerate as much as possible. Limiting the possibility of jettison to the event of a sea storm would be disadvantageous for sailors and merchants transporting their goods at sea. Therefore, it can be assumed that a threat from a pirate ship and the need to evade it also justified the throwing of goods overboard to relieve the ship and increase its speed.

18 D. 14.2.2.2 (Paulus libro trigensimo quarto ad edictum): tempestate gravi orta.

19 D. 14.2.4.1 (Callistratus libro secundo quaestionum): in tempestate.

20 D. 14.2 .6 (Iulianus libro octogensimo sexto digestorum): adversa tempestate.

21 In one of the jokes from the Philogelos collection (80), the goods are thrown overboard by the passengers, who also ask the hero of the joke to do likewise. It seems, however, that it was the captain who ordered the jettison, and the actions of the crew and passengers resulted from this. Cf. A. Tarwacka (2016a), 140-143; Tarwacka (2018a), 124-126. In the Acts of the Apostles (27.18-19) goods and equippment are thrown overboard by the crew.

22 Cutting down the mast also resulted in the need to settle because it served the interest of all persons on the ship. Cf. D. 14.2.3. Papinianus libro nono decimo responsorum: Cum arbor aut aliud navis instrumentum removendi communis periculi causa deiectum est, contributio debetur. 
Literary texts contain many references to pirate chases. In his Imagines, Philostratus, an orator from the turn of the second century AD, describes a painting depicting the myth of Dionysus and the pirates. ${ }^{23}$ The description of the pirate ship seems to reflect reality, not just a mythical tale. The Tyrrhenian ship was decorated with bright colours, eyes were painted on the bow, and the stern had the shape of a fish tail, which made the ship look like a sea monster. It is obvious, then, that one could spot the pirate ship from a distance. It was supposed to cause fear and panic but it could also have been a warning and a signal to flee as soon as possible.

It happened sometimes that pirates carried out reconnaissance at a port and looked for a ship that carried valuable cargo, and then they followed it to corner it on the high seas. If the crew or the passengers recognized the threat, they had a chance to escape. Such a situation was described by Plautus in his comedy Bacchides. ${ }^{24}$ The slave Chrysalus was recounting a fictional adventure with the pirates to old Nicobulus. Mnesilochus, Chrysalus' master, and at the same time Nicobulus' son, was to collect the debt, following his father's orders. Having loaded gold on the ship, the slave realized (as he claimed) they were being tracked by a pirate ship, actually sent by an embittered debtor. The pirates prepared an ambush to loot the gold, and as soon as the ship sailed out of the harbor, they began chasing it, rowing 'quicker than the wind and birds'. In such a situation, the decision was made to return to the port, and the following day, in front of pirates' eyes, the gold was taken to Diana's priest and deposited there ( $c f$. Zabłocki, 2015; Zabłocki, 2018). This fictitious tale suggest considerable acumen of sea robbers, who were able to obtain information about valuable cargoes. It is also worth noting that no robberies were carried out in ports, where there were many people: the pirates set an ambush at sea, where they had an advantage; above all, they were able to develop a higher speed than other ships. However, the behaviour of the potential victims is also very interesting: they returned to the safe harbor and disposed of the cargo which could have become the cause of the attack, depositing it for safekeeping.

The theme of a pirate ambush is also found in Heliodor's Aethiopica. ${ }^{25}$ The band's leader, in love with the beautiful heroine, asked when the Phoenician ship would leave the port. The pirates followed the ship for a long time but were unable to capture it: the merchant vessel was larger and with the favorable wind the surface of her sails ensured high speed. However, the wind abated which gave the sea robbers the advantage of the sea as they were able to sail very quickly by rowing, in which the small size of their ship proved an asset. When it became clear that the pirates would catch up with their victims, there was a confusion on the merchant ship: some were hiding, some wanted to fight, and others sug-

23 Philostr. Imag. 1.19.

24 Plaut. Bacch. 277-307.

25 Heliod. Aeth. 5.155; 5.159-160. 
gested fleeing in the small boats. Given the absence of wind, jettison would not have been justified. However, it is interesting to obtain the description of human behaviour in the face of imminent danger.

It also happened that an attacked crew took up a fight against the pirates, sometimes with good results. In his Memorabilia, the jurist Massurius Sabinus described the case of Marcus Octavius Herrenus, who was engaged in commercial activity and, attacked by sea robbers, managed to withstand their assault. ${ }^{26}$ The success was to be credited Hercules, to whom he made an offering, and consequently, Octavius build the hero a temple.

Pirate attacks were usually aimed at extorting a ransom. If one of the passengers paid it, the question arose whether and to what extent the others should participate in the loss suffered. Here, the Digest quotes the text of Paulus, who in turn draws on the opinion of Servius, Ofilius and Labeo in this matter.

D. 14.2.2.3. Paulus libro trigensimo quarto ad edictum: Si navis a piratis redempta sit, Servius Ofilius Labeo omnesque conferre debere aiunt: quod vero praedones abstulerint, eum perdere cuius fuerint. nec conferendum ei qui suas merces redemerit.

In this passage, three cases are analyzed: the ransoming of a ship from the hands of the pirates, the seizure of property, and the ransoming of their own goods only by one of the merchants. In the first situation, everyone should contribute to the ransom paid for the entire ship. This is due to the fact that the payer acted in the common interest and hence they are entitled to the reimbursement of the costs. The phrase omnes must be understood as referring to all the passengers as well as the owner of the ship, who undoubtedly was interested in ransoming the ship too (cf. Aubert, 2007, 163). The ratio legis here is identical with the regulation governing jettison, where one of the merchants loses their goods to save all the others (cf. Płodzien, 1961, 113 and 114). The basic premise justifying the claim for the reimbursement of the costs incurred is acting in the common interest. In the second case examined in the source text, a person whose property was looted by the pirates cannot claim compensation. The prerequisite of acting in the common interest is not met in this situation. The same applies to the third case: it would be unfounded to refund the costs to the merchant who ransomed only his goods because he acted only in his own interest (cf. Moschetti, 1983, 881).

It should also be noted that the text includes two different terms denoting the criminals: piratae, which unambiguously means pirates, and praedones, which may mean both sea and land robbers. The view expressed in the literature is that the latter term means the robbers the merchant met when he came ashore and that, therefore, only paying the ransom to the pirates, not the land robbers, was subject

26 Macrob. Sat. 3.6.11: Marcus, inquit, Octavius Herrenus, prima adolescentia tibicen, postquam arti suae diffisus est, instituit mercaturam, et bene re gesta decimam Herculi profanavit. Postea, cum navigans hoc idem ageret, a praedonibus circumventus fortissime repugnavit et victor recessit. Hunc in somnis Hercules docuit sua opera servatum. Cui Octavius impetrato a magistratibus loco aedem sacravit et signum, Victoremque incisis litteris appellavit. 
to settlement (cf. Ashburner, 2001, 254). This opinion, however, seems inconsistent with the ratio legis. It is evident that the settlement took place only when someone suffered a loss by acting removendi communis periculi causa. In ancient times, as already observed, pirates prowled both land and sea. Therefore, it does not seem that the key issue was the place where the ransom was paid. When the merchant or passenger ransomed the entire ship, everyone benefited from it and should therefore participate financially, proportionally to the value of their saved goods transported on the ship. If, on the other hand, the pirates robbed a part of the cargo, the loss was incurred by the owner.

The problem of ransom in the context of pirate raids features quite often in literary texts, but in most cases it concerns buying out kidnapped citizens from the hands of sea robbers, not a ship or the goods it carried.

The most notorious case related to this issue is, of course, the famed episode of the pirates kidnapping Julius Caesar, probably in 75 or $74 \mathrm{BC} .{ }^{27}$ Caesar got into the hands of the sea robbers most likely during a trip to Rhodes, where he was to study under the tutelage of the rhetoric master Molon. ${ }^{28}$ For almost forty days, he was held near the island of Farmacusa, after which a ransom of fifty talents was paid for him and he was released. He immediately gathered a fleet, apprehended his captors and crucified them all. Ancient authors emphasized Caesar's courage and the composure he kept while being among the pirates. According to Plutarch, when the robbers demanded a ransom for him in the amount of twenty talents, he laughed at them and raised the sum to fifty. ${ }^{29}$ When Caesar's slaves managed to collect the ransom in the cities of Asia Minor, he forced the pirates to provide hostages for those cities before he allowed the payment of money. ${ }^{30}$ In this case, however, the ransom surely concerned the person of Caesar, not the ship or goods.

The same applies to the cases of kidnapping described in rhetorical exercises. Prisoners would write letters home asking for the payment of ransom. Sometimes relatives brought the desired sum (at the same time exposing themselves to

\footnotetext{
27 A thorough analysis of sources with a view to dating this event was conducted by A.M. Ward in his two articles: Ward (1975) and Ward (1977). In the first of these, the researcher argued that the kidnapping of Caesar is more likely to have taken place in $81 \mathrm{BC}$, but in the second one he strongly opted for 75/74 BC. Osgood (2010), 334-336 supported the dating of the event to 74 or the turn of 74/73 BC. Cf. also Gelzer (1968), 23 ff.; Tarwacka (2009), 119 ff.; Tarwacka (2016b), 238 ff.

28 Cf. Suet. Div. Iul. 4.1; Plut. Caes. 3.1.

29 Plut. Caes. 2.1.

30 The ransom was paid out of the public money of these communities; Vell. Pat. 2.42.2: publica civitatium pecunia redemptus est. Gelzer (1968), 23-24, decided that Caesar had blamed these cities for inadequate protection of the coasts and that is why he had demanded the money. Still, Osgood (2010), $329 \mathrm{ff}$. , rightly noted that Caesar was known in this area and had a large clientele.
} 
enslavement as pirates did not always keep their word ${ }^{31}$ ), and sometimes no response came and then the kidnapped were sold as slaves or even killed. ${ }^{32}$

It should be assumed that the two cases described, i.e. paying the ransom for a ship and goods and buying out prisoners from the hands of pirates, constitute two institutions governed by completely different laws. The opinion of Servius, Ofilius and Labeo quoted by Paulus concerns only the ransom for things, which, moreover, is consistent with the legal structure of the jettison institution, which did not provide for the settlement in respect of free person's life, but only of items, as corporum liberorum aestimationem nullam fieri posse. ${ }^{33}$ Buying out a prisoner would not fulfill the condition of acting in the common interest because it was an individual advantage.

In conclusion, therefore, the regulations on participation in the loss incurred by persons traveling by ship were very consistent. The settlement was possible only in the case of acting in the common interest. In the event of jettison, its purpose was to relieve the vessel and increase its handling and speed. The potential causes included a sea storm and the risk of shipwreck, as well as - apparently - being pursued by pirates. However, if the ransom was paid to the pirates, reimbursement was possible only if everyone benefited from it, and therefore when the entire ship was ransomed. The settlement did not encompass individual items ransomed separately as well as the property that sea robbers had seized.

\section{Secondary Sources}

Alonso, J.L. (2012), Fault, strict liability, and risk in the law of the papyri, [in:] J. Urbanik (ed.), 'Culpa'. Facets of Liability in Ancient Legal Theory and Practice. Proceedings of the Seminar Held in Warsaw 17-19 February 2011, Warsaw, pp. 19-81.

Ashburner, W. (2001), The Rhodian Sea-Law, New Jersey.

Atkinson, K.M.T. (1974), Rome and the Rhodian Sea-Law, Iura 25, pp. 46-95.

Aubert, J.-J. (2007), Dealing with the Abyss: the Nature and Purpose of the Rhodian Sea-Law on Jettison ('Lex Rhodia de Iactu', D 14.2) and the Making of Justinian's 'Digest', [in:] J.W. Cairns, P. du Plessis (eds.), Beyond Dogmatics. Law and Society in the Roman World, Edinburgh, pp. 157-172.

Beresford, J. (2013), The Ancient Sailing Season, Leiden-Boston.

Ducin, S. (1997), Sztuka nawigacji w starożytnej Grecji i Rzymie, Lublin.

Gelzer, M. (1968), Caesar. Politician and Statesman, Oxford.

Gerkens, J.-F. (2005),'Vis maior' and 'vis cui resisti non potest', Fundamina 11.1, pp. 109-120. Jakab, E. (2008), Risikomanagement bei den naukleroi, [in:] Antike - Recht - Geschichte. Festschrift P. Pieler, Wien, pp. 1-16.

31 Cf. Sen. Contr. 7.4.1. Seneca admitted that even the fathers of the kidnapped were afraid of the arrival of pirates: eo loco (...) in quem venire etiam patres timuerunt (Sen. Contr. 1.6.2).

32 Sen. Contr. 7.4.5.

33 D. 14.2.2.2 (Paulus libro trigensimo quarto ad edictum). 
Kofanov, L.L. (2017), Il problema del contenuto della 'lex Rhodia' antica, [in:] idem, O. Sacchi (eds.), Il sistema "esterno" del diritto romano. 'Ius naturae', 'ius gentium' e diritto commerciale nel pensiero giuridico antico, Napoli, pp. 309-334.

Lentano, M. (2010), La figlia del pirata. Idee per un commento a Seneca, Controversiae I 6, Annali Online di Lettere - Ferrara 1, pp. 89-106, http://annali.unife.it/lettere/article/ viewFile/221/170.

De Martino, F. (1995), Lex Rhodia. Note di Diritto Romano Marittimo, [in:] Diritto economia e società nel mondo romano, vol. 1, Napoli, pp. 285-299.

Moschetti, C.M. (1983), Pirateria (storia), [in:] F. Calasso (ed.), Enciclopedia del diritto, vol. 33, Milano, pp. 873-879.

Ormerod, H. (1997), Piracy in the Ancient World, Baltimore (reed.).

Osgood, L. (2010), Caesar and The Pirates: or How to Make (and Break) an Ancient Life, GER 57.2, pp. 319-336.

Osuchowski, W. (1950), Appunti sul problema del "iactus" in diritto romano, Iura 1, pp. 292-300.

Płodzień, S. (1961), Lex Rhodia de iactu. Studium historyczno-prawne z zakresu rzymskiego prawa handlowo-morskiego, Lublin.

Pohl, H. (1993) Die römische Politik und die Piraterie im östlichen Mittelmeer vom 3. bis 1. Jahrhundert v. Chr, Berlin.

Rauh, N.K. (2003), Merchants, Sailors and Pirates in the Roman World, Stroud-Charleston.

Sobczyk, M. (2005), Siła wyższa w rzymskim prawie prywatnym, Torun.

de Souza, P. (1999), Piracy in the Graeco - Roman World, Cambridge.

Tarwacka, A. (2009), Romans and Pirates. Legal Perspective, Warszawa.

Tarwacka, A. (2016a), Obrócić prawo w żart. Instytucje prawne w zbiorze dowcipów 'Philogelos', Warszawa.

Tarwacka, A. (2016b), Piracy in Ancient Rome. The Crime and Its Punishment, [in:] S. Nowicki (ed.), "They Called Me to Destroy the Wicked and the Evil". Selected Essays on Crime and Punishment in Antiquity, Münster, pp. 229-246.

Tarwacka, A. (2018a), European Legal Culture through the Prism of Jokes. The Example of 'Philogelos', Wrocław.

Tarwacka, A. (2018b), The term "pirate" as a form of political invective in Republican Rome and its legal implications, [in:] I.G. Mastrorosa (ed.), Latrocinium maris. Fenomenologia e repressione della pirateria nell'esperienza romana e oltre, Roma, pp. 53-70.

Ward, A.M. (1975), Caesar and the Pirates, CP 70, pp. 267-268.

Ward, A.M. (1977), Caesar and the Pirates II. The Elusive M. Iunius Iuncus and the Year 75/74, AJAH 2, pp. 26-36

Zabłocki, J. (2015), Kontrakt depozytu a rozwój bankowości w starożytnym Rzymie. Uwagi na marginesie komedii Plauta, [in:] A. Tarwacka (ed.), 'Iura et negotia'. Księga jubileuszowa z okazji 15-lecia Wydziału Prawa i Administracji Uniwersytetu Kardynała Stefana Wyszyńskiego w Warszawie, Warszawa, pp. 341-351.

Zabłocki, J. (2019), Prawo w sztuce Plauta, czyli o banku w komedii 'Curculio', [in:] A. Dębiński, M. Jońca, I. Leraczyk (eds.), Ius est Ars Boni et Aequi. Sztuka w prawie, prawo w sztuce, Lublin, pp. 365-378.

Ziegler, K.H. (1980), 'Pirata communis hostis omnium', [in:] 'De iustitia et iure'. Festgabe für Ulrich von Lübtow zum 80. Geburtstag, Berlin, pp. 14-95. 


\section{Anna Tarwacka}

\section{USING LEX RHODIA IN THE CASE OF A PIRATE ATTACK}

The regulations on participation in loss incurred by persons traveling by ship were very consistent. The settlement was possible only in case of acting in the common interest. A jettison was carried out in order to relieve the vessel and increase its handling and speed. The cause could be a sea storm and the risk of wrecking the ship, but also, it seems, a pirate chase. In such case a person who suffered a loss could demand reimbursement from the ship's captain who could then sue other passengers. However, if the ransom was paid to the pirates, reimbursement was possible only if everyone benefited from it, and therefore when the entire ship was ransomed. Individual items ransomed separately and what the sea robbers had seized were not subject to the settlement. 